\title{
Revison of Alongatepyris (Hymenoptera: Bethylidae) with description of a new species from Colombia
}

\author{
Juan M. Vargas R. ${ }^{1} \&$ Celso O. Azevedo ${ }^{2,3}$ \\ ' Laboratorio de Artrópodos, Grupo de Biotecnología, Centro Internacional de Física, Universidad Nacional de Colombia. \\ Calle 45 Cra. 30 Edificio de Programas Especiales Manuel Ancizar, Segundo Piso, Bogotá D.C., Colombia. \\ ${ }^{2}$ Departamento de Biologia, Universidade Federal do Espírito Santo. Avenida Marechal Campos 1468, Maruípe, \\ 29040-090 Vitória, Espírito Santo, Brasil. E-mail: bethylidae@gmail.com \\ ${ }^{3}$ Corresponding author.
}

\begin{abstract}
Species of the Neotropical Alongatepyris Azevedo are rarely collected. It is recognized among Sclerodermini genera by having the body extremely flattened and the submedian cell of the fore wing small and completely closed. Originally monotypic, a second species, $A$. ingens sp. nov. from Colombia, is described and illustrated. This species is characterized by the absence of the radial vein of the fore wing. A diagnosis of $A$. platunissimus Azevedo, 1992 is presented and both species are compared. A key to species Alongatepyris is provided. KEY WORDS. Sclerodermini; Neotropical; taxonomy.
\end{abstract}

RESUMO. Revisão de Alongatepyris (Hymenoptera: Bethylidae), com descrição de uma espécie nova da Colômbia. Espécies do gênero Neotropical Alongatepyris Azevedo são raramente coletadas. $O$ gênero é reconhecido dentre os Sclerodermini por possuir o corpo extremamente achatado e a célula submediana da asa anterior pequena e completamente fechada. É descrita e ilustrada uma segunda espécie, Alongatepyris ingens sp. nov. da Colômbia. Esta espécie é caracterizada por não possuir a nervura radial da asa anterior. É apresentada uma diagnose de A. platunissimus Azevedo, 1992. É apresentada uma chave para as espécies do gênero.

PALAVRAS-CHAVE. Sclerodermini; neotropical; taxonomia.

Alongatepyris was described by AzEvedo (1992) to accommodate a very unusual Sclerodermini from the state of São Paulo, Brazil. This species has the body extremely flattened and the fore wing with the submedian cell completely closed and much smaller than the median cell. Thlastepyris Evans is the genus most closely related to Alongatepyris (Lanes \& Azevedo 2008), but in the former the median and submedian cells of the fore wings are incompletely divided (Evans 1973) because the base of the median vein is absent. Specimens of Alongatepyris are rarely collected; we were able to find only three specimens deposited in museums. Nothing is known regarding the hosts of Alongatepyris.

The goal of this study is to summarize the available information about this genus and propose a new species from Colombia.

\section{MATERIAL AND METHODS}

Efforts were made to study all available specimens of the genus. Besides, species of Thlastepyris and Bethylopsis Kieffer were investigated in order to find possible Alongatepyris species. Many collections were visited and loans were requested but no material was found. The material examined was kindly provided by the curators of the following institutions: (DCBU) Universidade Federal de São Carlos, Brazil (A.M. Penteado-Dias); (DZUP) Universidade Federal do Paraná, Brazil (G.A.R. Melo); (IAVH) Instituto Alexander von Humboldt, Colombia (M. Ospina).

Measurements and indices used in this study are as follows. body length: from the apex of clypeus to the posterior margin of the last metasomal segment, excluding male genitalia or female sting; length of head (LH): in frontal view, from vertex crest to median apical margin of clypeus; width of head (WH): in frontal view, its maximum width including eyes; width of frons (WF): in frontal view, its minimum width, usually about bottom of eyes; height of eye (HE): in lateral view, across its maximum height (length); ocelli-ocular line (OOL): measured in latero-dorsal view, the shortest distance from eye top to posterior ocellus; width of ocellar triangle (WOT): in frontal view, maximum width, including ocelli; diameter of anterior ocellus (DAO): in frontal view; distance of ocellar triangle to vertex: in dorso-posterior view; distance from posterior ocellus to vertex crest; vertex-ocular line (VOL): in dorsal view, distance from eye top to vertex crest.

The terms of integument sculpture follows HARRIS (1979) and general terms follow Evans (1964) and AzEvedo (1999). 


\section{Alongatepyris Azevedo, 1992}

Diagnosis. Body strongly flattened (Figs 2 and 7). Full winged; tegula present. Head slightly wider than maximum thorax width. Eye placed forward on head. Clypeus short. Antenna 13-segmented. Occipital carina absent. Palpal formula 6:3. Notaulus nearly absent. Parapsidal furrow and scutellar groove conspicuous. Propodeal disc with lateral, median and posterior carinae (Figs 1 and 6). Femora not well dilated. Fore wing elongate, with three closed cells, costal cell narrow, stigma small and prostigma large, submedian cell much shorter than median, these cells well separated from each other by median vein, radial vein tubular and narrow, pigmented (Figs 4 and 10).

\section{Key to species of Alongatepyris (females)}

1. Head subquadrate (Fig. 1); anterior margin of pronotal disc slightly convex (Fig. 1); propodeal disc conspicuously narrowing posterad (Fig. 1); fore wing with long radial vein, discoidal vein absent (Fig. 4) ...... A. platunissimus Azevedo

1'. Head elongate (Fig. 6); anterior margin of pronotal disc broadly convex (Fig. 6); propodeal disc slightly narrowing posterad (Fig. 6); fore wing without radial vein, discoidal vein short as stub (Fig. 10) A. ingens sp. nov.

\section{Alongatepyris platunissimus Azevedo, 1992 Figs 1-5}

Material examined. Holotype female: BRA[ZIL], S[ão] P[aulo], São Carlos, Fazenda Canchim, mata [= forest], 7.X.1988, suspensa [= ariel Malaise trap], L.A. Joaquim col. (DCBU). BrAZIL, Paraná: Jundiaí do Sul (Monte Verde Farm), 22.IX.1986, 1 female, armadilha [= trap] Malaise, Lev[antamento] Ent[omológico] Profaupar (DZUP).

Diagnosis. Female. Length about $4.0 \mathrm{~mm}$; LFW about 2.0 mm. Black. Head (Figs 1 and 2). Mandible with three apical teeth (Fig. 3). Clypeus extending backward into frons, median lobe rounded, surface of median area flat, without median carina. Eye with sparse setae. Antennal segment III 1.3x as long as wide. Frons strongly coriaceous, surface flat with linear elevation above clypeus which becomes linear depression from mid frons to anterior ocellus. WH 0.92-0.95x LH; WF 0.51-0.56x WH; WF 1.02-1.12x HE; OOL 1.67-1.86x WOT; head strongly flattened, its thick $0.32 \mathrm{x} \mathrm{LH}$; frontal angle of ocellar triangle obtuse; posterior ocelli distant from crest vertex $0.5 \mathrm{x}$ DAO. Vertex straight, with or without median callus, corner shortly rounded. VOL $0.8 \mathrm{x}$ HE. Temple straight and subparallel. Mesosoma (Figs 1 and 2). Surface of mesosoma mostly flat. Pronotal disc with series of small foveae paralleling posterior margin, which can be slightly angled forward medially. Notaulus short as stub and very weak, virtually absent. Parapsidal furrow strong, straight, absent on posterior anterior fifth or third of mesoscutum, not reaching posterior margin of mesoscutum. Scutellar groove narrow, deep, ends non-dilated and angled backward. Propodeal disc 1.1x longer than wide, median carina complete, basal triangle areolate, disc otherwise weakly coriaceous; declivity short, without carina, median area polished. Mesopleuron with shallow fovea nearly as large as mesopleuron, with central pit (Fig. 2). Fore wing with radial vein long (Fig. 4). Mid tibia not spinose. Fore femur 2.1x longer than wide. Claws simple. Metasoma with posterior margins of sternites IV-VI strongly bi-emarginate (Fig. 5).

\section{Alongatepyris ingens sp. nov. Figs 6-10}

Material examined. Holotype, female: Colombia, Guaviare: Tomachipán (playa río Inirida, $2^{\circ} 13^{\prime} 52^{\prime \prime} \mathrm{N}, 71^{\circ} 31^{\prime} 31^{\prime \prime} \mathrm{W}$ ), 29.I.1999, F. Fernández leg. (IAVH 31862).

Description. Female. Body length 2.9 mm; LFW $134 \mathrm{~mm}$. Color: body mostly black, palpi castaneous; mandible dark castaneous, median area of outer surface lighter; antenna dark castaneous, scape and flagellomeres infuscate; coxae and femora dark castaneous; trochanters castaneous; mid and hind tibiae dark castaneous, tarsi castaneous; tegula dark castaneous; wings hyaline, veins castaneous.

Head (Fig. 6). Mandible with four teeth, lower tooth sharpened (Fig. 8). Clypeus very short, median lobe rounded, median carina absent, base of clypeus extending back into frons. Eye sparsely hairy, situated forward on head. Antennal scrobe not carinate. Head very elongate, about $0.6 x$ length of mesosoma, width of head barely larger than maximum mesosomal width; WH 0.80x LH; WF 0.50x WH; WF 1.0x HE; OOL 1.8x WOT; head $0.32 \mathrm{x}$ as high as long (Fig. 7); frontal angle of ocellar triangle obtuse; posterior ocellus distant from vertex crest slightly more than own diameter. VOL 1.0x HE. Vertex concave medially with corner broadly rounded. First four antennal segments in ratio of about 10:5:2:3, segment III 1.0x as wide as long. Frons strongly coriaceous, surface above clypeus with polished flat linear elevation that does not surpass imaginary line between half length of eye. Sides of head parallel in lateral view. Palpal formula 6:3.

Mesosoma (Fig. 6). With the same texture of frons. Pronotal disc with median width $1.64 x$ median length; anterior margin conspicuously convex; posterior margin not paralleled by series of small foveae; length of pronotal disc/ mesoscutum/scutellum in about 2:1:1. Notaulus absent. Parapsidal furrow well impressed and straight, not reaching both anterior and posterior margins of mesoscutum. Scutellum wide posteriorly and broadly in contact with propodeal disc. Scutellar groove deep, progressively narrowing mesad, ends angled backward and not dilated. Propodeal disc 1.08x as long as maximum width, progressively narrowing posterad, anterior, median, lateral and posterior carinae complete, lateral carina not straight; propodeal disc strongly striate anteriorly; propodeal declivity short and striate; side-piece of propodeum coriaceous with weak striae. Mesopleuron with shallow large fovea occupying nearly entire surface of mesopleuron, outlined by carina; central pit small (Fig. 9). Propleuron angulate in dorsal view. Mesosternum without striae or foveae, with shallow 

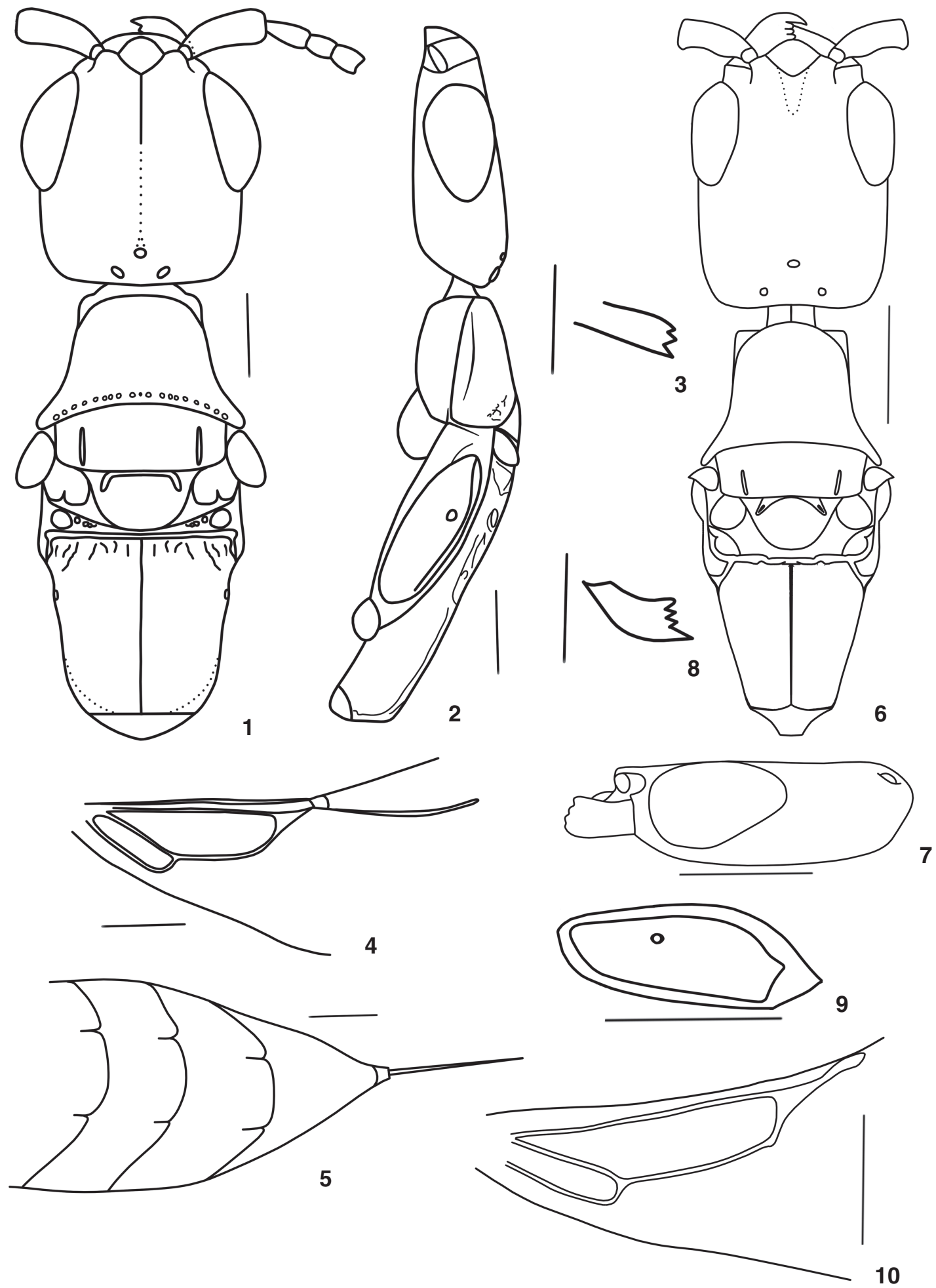

Figures 1-10. (1-5) Alongatepyris platunissimus: (1) head and mesosoma, dorsal view; (2) head and mesosoma, lateral view; (3) mandible, frontal view; (4) fore wing, dorsal view; (5) apex of metasoma, ventral view; (6-10) A. ingens sp. nov.: (6) head and mesosoma, dorsal view; (7) head, lateral view; (8) mandible, frontal view; (9) mesopleuron, dorsal view; (10) fore wing, dorsal view. Scale bar = $250 \mu \mathrm{m}$. 
depression near margin of mid coxa. Fore wing with radial vein absent, basal vein with thickening medially (Fig. 10). Mid tibia not spinose. Fore femur $2.2 \mathrm{x}$ as long as wide. Claws simple and much arched.

Metasoma. Wholly polished. Tergites and sternites with a row of setae posteriorly, former ones with few lateral setae. Posterior margin of sternites IV-VI evenly curved and bi-emarginate. Transverse section elliptical. Part exposed of sting 0.03 $\mathrm{mm}$ long. Length of metasoma $1.55 \mathrm{x}$ length of mesosoma.

Etymogeny. The specific epithet refers to the large size of the head.

\section{DISCUSSION}

The only known specimen of $A$. ingens was collected 3,600 $\mathrm{km}$ away in a straight line from the type locality of $A$. platunissimus (Brazil, São Paulo, São Carlos). This broadens considerably the distribution of the genus, since the known distribution was restricted to two sites in southern Brazil, which are distant from each other about $290 \mathrm{~km}$ in a straight line. This gap suggests that the species of this genus may have a broader distribution within South America.

Although Azevedo (1992) stated that Alongatepyris has the radial vein of the fore wings long, this applies only to $A$. platunissimus, since this vein is absent in A. ingens sp. nov. This broadens the concept of the genus. However, A. ingens sp. nov. fits perfectly well in Alongatepyris with respect to other generic characters. It is important to point out that the characters related to wing venation are among the most useful ones for taxonomic and phylogenetic studies of the Sclerodermini (see LANEs \& AzEvedo 2008).

Alongatepyris ingens sp. nov. differs from A. platunissimus by many features. The main differential characters are indicated in the key. Besides such differences, A. ingens sp. nov. has the clypeus less projected backward, the median depression does not reach the anterior ocellus, whereas in $A$. platunissimus the clypeus is well projected backward and the linear frontal depression reaches the anterior ocellus. In addition, in $A$. ingens sp. nov. the mandibles have four teeth, the head is almost evenly high in lateral view, and the scutellar groove is narrower medially, whereas A. platunissimus has three mandibular teeth, the head progressively narrowing anterad in lateral view, and the scutellar grove evenly narrow.

\section{ACKNOWLEDGMENTS}

We are most grateful to all curators cited in the text for the loan of the material examined; to Monica Ospina and Diana Aires for the reception during the visit of the second author to IAVH; to Diana Aires and her family for hosting the second author very kindly in their home while in Bogotá going to and back from IAVH; to Monica Ospina on behalf of IAVH for providing us free hotel accommodation while visiting IAVH; to Homero Penteado and Marcelo T. Tavares for transporting types from and to DCBU; to Gabriel Melo who provided us pictures of the specimen from DZUP; to Isabel Alencar who scanned the plates; to Felipe Fraga who edited the plates; to CNPq by the fellowship and financial support (grants \#303216/2004-2 and \#306331/2007-7) and Programa Taxonomia (grant \#563953/05-5).

\section{LITERATURE CITED}

Azevedo, C.O. 1992. Sobre os Sclerodermini (Hymenoptera, Bethylidae, Epyrinae) da região de São Carlos, SP. Revista Brasileira de Entomologia 36: 561-567.

Azevedo, C.O. 1999. Revision of the Neotropical Dissomphalus Ashmead, 1893 (Hymenoptera, Bethylidae) with median tergal processes. Arquivos de Zoologia 35: 301-394.

Evans, H.E. 1964. A synopsis of the American Bethylidae (Hymenoptera, Aculeata). Bulletin of the Museum of Comparative Zoology 132: 1-222.

Evans, H.E. 1973. Further studies on South American Bethylidae (Hymenoptera). Proceedings of the Entomological Society of Washington 75: 194-204.

Harris, R.A. 1979. A glossary of surface sculpturing. Occasional Papers in Entomology 28: 1-31.

Lanes, G.O. \& C.O. Azevedo. 2008. Phylogeny and Taxonomy of Sclerodermini (Hymenoptera, Bethylidae, Epyrinae). Insect Systematics and Evolution 39: 55-86.

Submitted: 11.VII.2008; Accepted: 06.XII.2008.

Editorial responsibility: Gabriel L.F. Mejdalani 